\title{
Annual Elections \\ Honorary Officers, Council and Court of Electors
}

Fellows and Members of the College are reminded of their rights in connection with the forthcoming elections for the offices of Dean, Registrar, Treasurer, Editor, Librarian and Sub-Deans. All Honorary Officers are eligible for re-election.

The nominating meeting of Council will be held on 19 March 1981, and the last date for receiving nominations will therefore be 17 April 1981. Nominations may also be submitted for vacancies on the Court of Electors and for Elected Members of Council. The relevant Bye-Laws and Regulations are printed below. Lists of Officers and members of Council and the Court of Electors were published in the Bulletin for January.

\section{Extracts from Bye-Laws and Regulations}

Bye-LaW XII THE OTHER HONORARY OFFICERS

1. The Council shall, in accordance with the Regulations, make its nominations for the offices of Dean, Registrar, Treasurer, Editor, Librarian and Sub-Deans at the first meeting after the name of the President for the next ensuring College year has become known. Written nominations for the above Honorary Officers, accompanied in each case by the nominee's written consent to stand for election, may also be lodged with the Registrar at such time as may be prescribed by the Regulations, provided that each such nomination is supported in writing by not less than twelve Members of the College who are not members of the Council.

2. The Dean, Registrar, Treasurer, Editor and Librarian shall be elected from amongst the Fellows, and the SubDeans shall be elected from amongst the Members of the College, by the Members of the College, in each case in accordance with the procedure prescribed by the Regulations.

Regulation XII ELECTION OF THE OTHER HONORARY OFFICERS

1. The method of electing the Honorary Officers other than the President and the Vice-Presidents shall be the same as that for electing the President", save that nominations from Members of the College who are not members of the Council shall be lodged with the Registrar between the first day of January in any calendar year and the date which is four clear weeks after that meeting of the Council which is

-i.e. Written nominations, accompanied in each case by the nominee's written consent to stand for election, may be lodged with the Registrar, provided that each such nomination is supported in writing by not less than twelve Members of the College who are not members of the Council. An election by ballot shall be held in accordance with the provisions of the Regulations. first held after the name of the President for the next ensuing College year has become known, or (as the case may be) which is four clear weeks after that meeting of the Council which, in the case of a tie on the second ballot, determines the election of the President.

\section{Regulation XIV THE TREASURER}

7. The Treasurer shall not hold office as such for a term of more than seven consecutive College years.

\section{Regulation XVIII THE SUB-DEANS}

2. No Sub-Dean shall hold office as such for a term of more than five consecutive College years.

\section{Bye-Law XXI THE COURT OF ELECTORS}

5. At the first meeting of the Council after the name of the President for the next ensuing College year has become known, the Council shall nominate a sufficient number of candidates for appointment as Electors to ensure an election, which will be held by a postal ballot of all Members of the College in the manner prescribed by the Regulations. Additional nominations may be lodged with the Registrar between the beginning of the then current calendar year and the end of four clear weeks after the meeting of the Council above referred to. No such nomination shall be valid unless it be supported in writing by twelve Members of the College and accompanied by the nominee's written consent to serve if elected.

Regulation XIX THE COUNCIL

3. The Council shall, at its first meeting in each College year after the name of the President for the next ensuing College year has become known, nominate for election to the Council twelve or more Members of the College. Any nominee who is proposed and seconded and gives his consent in writing to serve shall be validly nominated. Any twelve Members of the College may make nominations in writing at any time between the first day of January in each year and the date which is four clear weeks after the meeting of the Council at which its nominations are made. Nominations other than those made by the Council shall be lodged with the Registrar and accompanied by the written consent of the candidate to serve if elected. Should there be more nominations than vacancies, an election shall be held by ballot of the Members of the College. The ballot paper shall not indicate the methods of nomination or the names of those nominating. If the number of nominees does not exceed the number of vacancies, these nominees shall be declared elected at the first meeting, whether of the Council or of the Executive and Finance Committee, after the expiry of the period of four clear weeks in this paragraph referred to. 